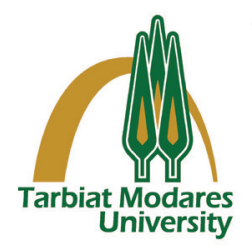

\title{
Parvovirus B19 Susceptibility among Women of Child- bearing Age: A Sero-Survey in the North East of Iran
}

\section{A R T I C L E I N F O}

Article Type

Original Research

Authors

Farnaz Zahedi Avval, $P h D$

Marziyeh Khazaei, $M D^{1}$

Monireh Davoodian, $M S C^{1}$

Lida Jarahi, $M D^{2 *}$

Masoud Youssefi, $P h D^{3^{*}}$

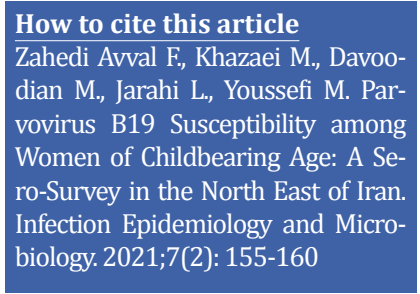

${ }^{1}$ Department of Clinical

Biochemistry, Faculty of Medicine, Mashhad University of Medical

Sciences, Mashhad, IRAN

${ }^{2}$ Department of Community

Medicine, Faculty of Medicine,

Mashhad University of Medical

Sciences, Mashhad, IRAN

${ }^{3}$ Department of Microbiology and Virology, Faculty of Medicine, Mashhad University of Medical Sciences, Mashhad, IRAN

\section{* Correspondence}

Address: Emam Reza Square, Emam Reza University Hospital, School of Medicine, Mashhad, IRAN.

Tel: 05138002365

Postal Code: 9137913316

Youssefim@mums.ac.ir

\section{A B S T R A C T}

Backgrounds: Parvovirus B19 (B19V) infection is mainly manifested as erythema infectiosum in children. Primary B19V infection during pregnancy is accompanied by a 30\% risk of fetal infection, especially in epidemic conditions. Given the important impact of parvovirus B19 infection on maternal and neonate health, this study assessed parvovirus B19 susceptibility among women of childbearing age in Mashhad, northeast Iran.

Materials \& Methods: Serum samples were collected from 185 women aged 20-35 years living in Mashhad. Cluster sampling was performed in different health centers located in the city to cover the main city area. A commercial ELISA kit was used to measure IgG antibodies against B19V. This study was performed in accordance with the ethical standards mentioned in the declaration of Helsinki. Informed consent was taken from all participants. A questionnaire was filled by each participant. SPSS software Version 11.5 was used for statistical analyses.

Findings: Anti-B19 IgG was observed in about 31\% of women. Seroprevalence of anti- B19 antibodies among different age groups (with 5-year intervals) was not significantly different $(p=839)$. Also, there was no significant difference among different city areas of Mashhad in terms of anti-B19 IgG seropositivity $(.39, p>.05)$.

Conclusion: The prevalence of parvovirus B19 infection varies in different parts of the world. Comparing to other reports, the present study revealed a rather low immunity against parvovirus B19 among women in Mashhad. These findings highlight the potential risk of B19 infection in non-immune/susceptible mothers, which may lead to sever outcomes, especially during epidemics.

Keywords: Parvovirus B19, IgG, Iran.

\section{CITATION LINKS}

[1] Woolf AD, Campion GV, Chishick A, Wise S, Cohen ... [2] Lehmann HW, Kühner L, Beckenlehner K, Müller-Godeffroy ... [3] Moffatt S, Tanaka N, Tada K, Nose M, Nakamura M, ... [4] Henriques I, Monteiro F, Meireles E, Cruz A, Tavares G, Ferreira M, et al. Prevalence ... [5] Groeneveld K, Van Der Noordaa J. Blood ... [6] Norja P, Lassila R, Makris M. Parvovirus transmission ... [7] Rodis JF, Quinn DL, Gary GW, Anderson LJ, Rosengren S, Cartter ML, et al. Management ... [8] LaMonte AC, Paul ME, Read JS, Frederick MM, Erdman DD, Han LL, et al. Persistent ... [9] Gratacós E, Torres P-J, Vidal J, Antolín E, Costa J, Jimenez de Anta MT, et al. The ... [10] Daly P, Corcoran A, Mahon B, Doyle S. High-sensitivity ... [11] Heegaard ED, Brown KE. Human ... [12] Centers for Disease Control (CDC). Risks ... [13] Babaie J, Amiri S, Mostafavi E, Hassan N, Lotfi P, Esmaeili ... [14] Erfanianahmadpoor M, Nasiri R, Vakili R, Hassannia T. Seroprevalence ... [15] Maksheed MA, Pacsa A, Essa SS, Ahmed MA, Monem RA, Surkouh M. The prevalence of ... [16] Małafiej E, Wilczyński J, Szaflik K, Śpiewak E, Nowakowska D, Marcinek ... [17] Zajkowska A, Garkowski A, Czupryna P, Moniuszko A, Król ME, Szamatowicz J, et al. Seroprevalence of parvovirus B19 antibodies among young pregnant women or planning pregnancy, tested for toxoplasmosis. Przegl Epidemiol. 2015;69(3):479-82. [18] Abiodun I, Opaleye 00, Ojurongbe 0, Fagbami AH. Seroprevalence of parvovirus B19 IgG and IgM antibodies among pregnant women in... [19] Yaegashi N, Okamura K, Hamazaki Y, Yajima A, Shiraishi H, Sugamura K. Prevalence of anti-human parvovirus antibody in pregnant women. Nihon... [20] Habibzadeh S, Peeri-Doghaheh H, Mohammad-Shahi J, Mobini E, Shahbazzadegan S. The prevalence of parvovirus B19 infection among pregnant women of Ardabil in... [21] Khameneh ZR, Hanifian H, Barzegari R, Sepehrvand N. Human parvovirus B19 in Iranian pregnant women: A serologic survey. Indian J Pathol... [22] Ziyaeyan M, Rasouli M, Alborzi A. The seroprevalence of parvovirus B19 infection among to-be-married girls, pregnant women, and... [23] Siennicka J, Stefanoff P, Trzcińska A, Rosińska M, Litwińska B. Seroprevalence study of parvovirus B19 in Poland. Przegl ... [24] Emiasegen SE, Nimzing L, Adoga MP, Ohagenyi AY, Lekan R. Parvovirus B19 antibodies and correlates of infection in pregnant women attending an antenatal clinic in central Nigeria. Mem Inst Oswaldo... 


\section{Introduction}

Parvovirus B19 was first discovered accidentally in healthy blood donors in 1975. Human parvovirus B19 belongs to the parvoviridae family, with a characteristic ssDNA genome. This pathogen is a small virus whose genome encodes structural vp1 and vp2 proteins as well as nonstructural NS1 protein ${ }^{[2]}$.

Parvovirus infection has been known as fifth disease since 1983 , it is also an important pathogen mainly due to causing intrauterine fetal death and hydrops fetalis ${ }^{[3]}$. Erythema infectiosum or fifth disease is the most common clinical manifestation of the infection in children, characterized by mild fever and rash ${ }^{[4-5]}$. The parvovirus B19 infection could result in erythroblastopenia, leading to severe fetal anemia. The virus replicates in red blood cell (RBC) precursors in the bone marrow, which leads to bone marrow suppression ${ }^{[6]}$.

The parvovirus B19 usually infects humans through the respiratory system and could be transmitted through blood transfusions and blood products ${ }^{[6]}$. The virus could also be transmitted through vertical transmission route (from mother to fetus) ${ }^{[7]}$. In most cases, the virus is eradicated from the body with long lasting IgG antibody; however, in some cases, especially with immunodeficiency conditions, the virus persists and continues to replicate in some organs ${ }^{[8]}$. The fetus seems to be most susceptible to B19 infection in the first and second trimesters of pregnancy, especially from 10 to 20 weeks, due to time interference with the most changes in the erythroid precursors ${ }^{[9]}$. B19 has a great interest to infect dividing cells, especially erythroblasts. The fetal red blood cells increase up to 30 -fold between the $3^{\text {rd }}$ and $6^{\text {th }}$ months of pregnancy, which put the fetus at risk of anemia if exposed to B19 [10]. Primary parvovirus infection in pregnant women could lead to intrauterine fetal involvement in some cases ${ }^{[11]}$; this condition is called hyrops fetalis, a rare but important cause of fetal death. The virus could be transmitted through placenta. The fetal infection leads to RBC precursors infection, severe anemia, and endothelial involvement, all of which lead to cardiac failure. In addition, multi organ involvement including hepatitis and myocarditis, may ultimately lead to fetal hydrops. Fetal anemia could be due to RBC precursors infection [11]. During the third trimester of pregnancy, the fetus may have a better immune response to B19 infection, which may be associated with fewer fetal deaths during this period of pregnancy ${ }^{[12]}$. Therefore, B19V infection is one of the TORCH infections which are important during pregnancy. The seropositivity associated with some other causes of TORCH infections has been studied in the northeast of Iran (13-14), but little is known about the seroprevalence of B19 in this region.

Objectives: The present study was designed to investigate anti-parvovirus B19 antibody levels in the sera of fertility-aged women in Mashhad, Iran.

\section{Materials and Methods}

Study design \& study population: Serum samples were taken from 185 fertility-aged women (20-35 years) living in Mashhad. Cluster sampling was performed in different health centers located in the city to cover the main city area. Sampling was done equally in each center of women in different age groups. Serum samples were kept at $-80{ }^{\circ} \mathrm{C}$ until used for ELISA assay.

The required information about age, marital status, history of abortion, any other major clinical conditions, and drug usage was collected through a questionnaire provided to patients.

ELISA assay: A commercial ELISA kit was used to measure IgG against parvovirus B19 (Parvovirus B19 IgG ELISA, Antibodies- 
Table 1) Seroprevalence of B19 IgG antibodies in a total of 185 women of reproductive age in Mashhad. There was no significant difference between different age groups $(p=0.39)$.

\begin{tabular}{cccc}
\hline Age Group (Years) & Group 1 (20-25) & Group 2 (26-30) & Group 3 (31-35) \\
\hline Total number (n) & 57 & 61 & 67 \\
\hline Positive cases (n) & 18 & 19 & 20 \\
\hline Seropositivity (\%) & 31.58 & 31.15 & 29.86 \\
\hline
\end{tabular}

online, Germany). The kit had a specificity of $100 \%$ and sensitivity of $98 \%$. The IgG antibody against parvovirus B19 was measured based on the manufacturer's instructions. Briefly, serum samples or controls were added into each well precoated with parvovirus B19 antigen (VP1protein). Next, anti-human parvovirus B19 IgG antibody and HRP (horseradish peroxidase) conjugated anti-human IgG antibodieswereaddedinto the wells. Afterthe washing steps to remove unbound materials, the TMB substrate solution was added to each well to develop the color change. After the addition of the stop solution, OD values were read using a spectrophotometer at a wavelength of $450 \mathrm{~nm}$. Positive and negative controls were used in each experiment, and the results were interpreted based on the OD values and cut off calculations according to the kit manual.

Statistical analysis: The results were analyzed using SPSS software (Version 22). Analysis of data and statistical comparisons were performed using ANOVA test. A $p$ value of less than 0.05 was considered as statistically significant in all calculations.

\section{Findings}

The number of participants in different age groups was as follows: 57 individuals in the age group of 20-25 years (Group 1), 61 in the age group of 26-30 years (Group 2), and 67 in the age group of 31-35 years (Group 3). Totally, anti-parvovirus B19 antibody was found in $30.81 \%$ of all participating women. None of the participants had a history of inherited or familial diseases, and $9.2 \%$ of all participants had minor underlying disorders. The frequency of previous abortions and stillbirths was 9.45 and $1.6 \%$, respectively. The seroprevalence of parvovirus 19 IgG antibody is shown in Table 1. There was no significant difference between the age groups ( $p=0.39)$ regarding the seroprevalence of B19 IgG antibody. Frequency evaluation of abortion history showed no significant difference between the three age groups. There was no significant difference in underlying conditions between the age groups. As expected, a higher number of previous pregnancies and children was observed in the age group of 31-35 years $(p<0.001)$.

The number of previous pregnancies and childbirth was not statistically different in women with or without parvovirus B19 antibody $(p=0.59)$.

\section{Discussion}

This study reported the prevalence of antiparvovirus B19 antibodies among women of childbearing ages in Mashhad located in northeastern Iran. Generally, the fertility age is considered to be from $18-40$ years; however, in this study, the most common fertility age of 20-35 years was chosen to cover major pregnancies in the community. Globally, the results of many studies have shown that B19 seroprevalence among women of childbearing age is highly diverse. For example, the seroprevalence of $\operatorname{IgG}$ and IgM antibodies against B19V in pregnant women in Kuwaiti has been reported to be 
53.3 and $2.2 \%$, respectively ${ }^{[15]}$. In different regions of Poland, IgG antibody prevalence in pregnant women has been reported as 35 and $43.6 \%{ }^{[16-17]}$. In a study in Nigeria, 231 pregnant women were assessed, of whom only $20 \%$ were positive for IgG antibodies [18], and in Japan, 33\% of pregnant women had specific IgG for the virus ${ }^{[19]}$.

In England, Japan, and Spain, the prevalence of IgG in pregnant women has been reported to be 53,23 , and $35 \%$, respectively ${ }^{[15]}$. Also, a study in the United States showed that serum levels were positive in less than 19\% of children and $67 \%$ of people over 49 years. Some studies have been conducted in Iran on the prevalence of anti-B19 antibodies, showing different seroprevalence values; however, there is no sufficient data on anti-B19 antibodies prevalence in eastern region of the country ${ }^{[20-21]}$. It seems that seroprevalence in Mashhad is closer to the reported global ranges.

The main goal of this study was to screen women of childbearing age susceptible to B19 virus. The obtained data showed that anti-B19 IgG antibodies were positive in approximately $31 \%$ of all participating women, indicating that almost $70 \%$ of the study population were susceptible to the B19 virus, thereby probably leading to fetal complications during pregnancy. Probably B19 prevalence is related to age ${ }^{[22]}$. The seroprevalence of anti-B19 IgG among different age groups was not significantly different. This finding is contrary to other studies reporting a remarkable increase in seropositivity along with increasing age [17, 19, 22-24]. This finding might be due to low frequency of circulating viruses in the study region or statistically rather small sample size.

Unlike the present study, similar studies conducted in Iran have shown a prevalence of more than $60 \%$ for IgG among women of reproductive age ${ }^{[20]}$. Studies in the northwest of the country have shown a seroprevalence of 75.6 and $69.1 \%$ in studied women ${ }^{[20-21]}$. The reported seroprevalences are remarkably higher than that observed in the present study. This difference might be due to climate variation, resulting in greater B19 circulation in western areas. Therefore, it seems the numbers of circulating viruses and related infections are higher in western Iran. The lower immunity against B19 virus in eastern Iran is a warning of possible epidemics with severe mother-child outcomes in this region.

The results of this study should be interpreted according to several limitations: First, as mentioned earlier, the age range of the participants in this study was considered slightly less than the reproductive age of the total female population. The reason for considering the age range of 20 to 35 years in this study is high-risk pregnancies and more abortions at the age of less than 20 or more than 35 years, which could affect the results. However, according to the results, most pregnancies in the study region occurred between 20 and 35 years, and this age range well covered childbearing age. Second, larger sample sizes might strengthen the study, though the sample size in this study provided a clue to the situation in the study area.

Similar to Habibzadeh et al. (2016), no significant relationship was found between residence areas and IgG-positive prevalence ${ }^{[20]}$. Thus, socioeconomic conditions do not seem to be a major determinant. Despite the above-mentioned limitations, the results are considerable due to the use of cluster sampling method covering the main city area, novelty of results, significant difference between the results and those obtained in other parts of the country, as well as obtaining remarkable potential clinical outcomes. Overall, this study results are also a warning to gynecologists, and 
health principles education seems to be necessary. Given that about $70 \%$ of women in the area were susceptible to the infection, this situation could have severe social consequences, especially in viral epidemic conditions. It is highly recommend that future interventions be performed to screen, prevent, and surveille the epidemic to improve mother-child health.

Acknowledgments: The study was MD thesis of author M.K. We thank the health centers of Mashhad their kind assistance in sample collection.

Ethical permission: This study was approved ethically by the Research Council of Mashhad University of Medical Sciences ( IR.MUMS. REC.1394.56).

Conflicts of interests: No conflict of interest to declare.

Authors' contribution: Conceptualization: FZA and MY, Data curation and formal analysis: MY, LJ; Investigation: MK and MD; Methodology and project administration: FZA and MY; Supervision: MY; Validation: MY, FZA and LJ; Writing of original draft: FZA and MD; Writing, reviewing, and editing: FZA and MY.

Fundings: This work was supported by a grant from Mashhad University of Medical Sciences (grant number 930657).

Consent to participate: An informed consent was taken from each participant prior to enrolment in this study.

\section{References}

1. Woolf AD, Campion GV, Chishick A, Wise S, Cohen BJ, Klouda PT, et al. Clinical manifestations of human parvovirus B19 in adults. Arch Intern Med. 1989;149(5):1153-6.

2. Lehmann HW, Kühner L, Beckenlehner K, Müller-Godeffroy E, Heide K-G, Küster $\mathrm{R}-\mathrm{M}$, et al. Chronic human parvovirus B19 infection in rheumatic disease of childhood and adolescence. J Clin Virol. 2002;25(2):135-43.

3. Moffatt S, Tanaka N, Tada K, Nose M, Nakamura M, Muraoka O, etal. A cytotoxic nonstructural protein, NS1, of human parvovirus B19 induces activation of interleukin-6 gene expression. J Virol. 1996;70(12):8485-91.

4. Henriques I, Monteiro F, Meireles E, Cruz A, Tavares G, Ferreira M, et al. Prevalence of parvovirus B19 and hepatitis A virus in Portuguese blood donors. Transfus Apher Sci. 2005;33(3):305-9.

5. Groeneveld K, Van Der Noordaa J. Blood products and parvovirus B19. Neth J Med. 2003;61(5):154-6.

6. Norja P, Lassila R, Makris M. Parvovirus transmission by blood products-a cause for concern? $\mathrm{Br} \mathrm{J}$ Haematol. 2012;159(4):385-93.

7. Rodis JF, Quinn DL, Gary GW, Anderson LJ, Rosengren S, Cartter ML, et al. Management and outcomes of pregnancies complicated by human B19 parvovirus infection: A prospective study. Am J Obstet Gynecol. 1990;163(4):116871.

8. LaMonte AC, Paul ME, Read JS, Frederick MM, Erdman DD, Han LL, et al. Persistent parvovirus B19 infection without the development of chronic anemia in HIVinfected and-uninfected children: The women and infants transmission study. J Infect Dis. 2004;189(5):847-51.

9. Gratacós E, Torres P-J, Vidal J, Antolín E, Costa J, Jimenez de Anta MT, et al. The incidence of human parvovirus B19 infection during pregnancy and its impact on perinatal outcome. J Infect Dis. 1995;171(5):1360-3.

10. Daly P, Corcoran A, Mahon B, Doyle S. High-sensitivity PCR detection of parvovirus B19 in plasma. J Clin Microbiol. 2002;40(6):1958-62.

11. Heegaard ED, Brown KE. Human 
parvovirus B19. Clin Microbiol Rev. $2002 ; 15(3): 485-505$.

12. Centers for Disease Control (CDC). Risks associated with human parvovirus B19 infection. MMWR. 1989;38(6):81-8.

13. Babaie J, Amiri S, Mostafavi E, Hassan N, Lotfi P, Esmaeili Rastaghi AR, et al. Seroprevalence and risk factors for Toxoplasma gondii infection among pregnant women in Northeast Iran. Clin Vaccine Immunol. 2013;20(11):1771-3.

14. Erfanianahmadpoor M, Nasiri R, Vakili R, Hassannia T. Seroprevalence, transmission, and associated factors of specific antibodies against cytomegalovirus among pregnant women and their infants in a regional study. Saudi Med J. 2014;35(4):360-4.

15. Maksheed MA, Pacsa A, Essa SS, Ahmed MA, Monem RA, Surkouh M. The prevalence of antibody to human parvovirus B19 in pregnant women in Kuwait. Acta Trop. 1999;73(3):225-9.

16. Małafiej E, Wilczyński J, Szaflik K, Śpiewak E, Nowakowska D, Marcinek P. Analysis of complications during pregnancy in women with serological features of acute toxoplasmosis or acute parvovirosis. Ginekol Pol. 2007;78(3).

17. Zajkowska A, Garkowski A, Czupryna P, Moniuszko A, Król ME, Szamatowicz J, et al. Seroprevalence of parvovirus B19 antibodies among young pregnant women or planning pregnancy, tested for toxoplasmosis. Przegl Epidemiol. 2015;69(3):479-82.

18. Abiodun I, Opaleye 00, Ojurongbe
O, Fagbami AH. Seroprevalence of parvovirus B19 IgG and IgM antibodies among pregnant women in Oyo State, Nigeria. J Infect Dev Ctries. 2013;7(12):946-50.

19. Yaegashi N, Okamura K, Hamazaki Y, Yajima A, Shiraishi H, Sugamura K. Prevalence of anti-human parvovirus antibody in pregnant women. Nihon Sanka Fujinka Gakkai Zasshi. 1990;42(2):162-6.

20. HabibzadehS,Peeri-DoghahehH,MohammadShahi J, Mobini E, Shahbazzadegan S. The prevalence of parvovirus B19 infection among pregnant women of Ardabil in 2013. Iran J Microbiol. 2016;8(3):214-8.

21. Khameneh ZR, Hanifian H, Barzegari R, Sepehrvand N. Human parvovirus B19 in Iranian pregnant women: A serologic survey. Indian J Pathol Microbiol. 2014;57(3):442-4.

22. Ziyaeyan M, Rasouli M, Alborzi A. The seroprevalence of parvovirus B19 infection among to-be-married girls, pregnant women, and their neonates in Shiraz, Iran. Jpn J Infect Dis. 2005;58(2):95-7.

23. Siennicka J, Stefanoff P, Trzcińska A, Rosińska M, Litwińska B. Seroprevalence study of parvovirus B19 in Poland. Przegl Epidemiol. 2005;60(3):571-80.

24. Emiasegen SE, Nimzing L, Adoga MP, Ohagenyi AY, Lekan R. Parvovirus B19 antibodies and correlates of infection in pregnant women attending an antenatal clinic in central Nigeria. Mem Inst Oswaldo Cruz. 2011;106(2):227-31. 